\title{
ANALISIS SISTEM PERHITUNGAN RANCANG BANGUN RUMAH
}

\section{BERBASIS WEB}

\author{
Lilis Anggraini $^{1)}$, Yusri Ikhwani ${ }^{2}$ \\ ${ }^{1}$ Fakultas Teknologi Informasi Universitas Islam Kalimantan Muhammad Arsyad Al Banjari Banjarmasin \\ email : lilis.anggraini0205@gmail.com \\ ${ }^{2}$ Fakultas Teknologi Informasi Universitas Islam Kalimantan Muhammad Arsyad Al Banjari Banjarmasin \\ email : yusri.ikhwani@gmail.com
}

\begin{abstract}
ABSTRAK
Pentingnya Komputerisasi merupakan salah satu pendukung berkembangnya teknologi yang telah memasuki hampir ke semua bidang kehidupan. Perkembangan teknologi ini juga didukung oleh industri hardware (perangkat keras) dan software (perangkat lunak) komputer yang terus berkembang dan semua ini telah memberikan banyak dampak positif bagi kehidupan masyarakat. Dengan pesatnya teknologi tersebut kebutuhan masyarakat akan sebuah pelayanan yang tidak dibatasi ruang dan waktu saat ini mendorong semakin dibutuhkannya suatu sistem maupun perangkat lunak yang akan membantu proses peningkatan kualitas pelayanan terhadap customer (pelanggan). Salah satu contoh kebutuhan masyarakat yang merupakan kebutuhan pokok manusia yaitu tempat tinggal. Tempat tinggal biasanya berwujud bangunan rumah, tempat berteduh atau struktur lainnya yang digunakan sebagai tempat manusia tinggal. Rumah adalah salah satu bangunan yang dijadikan tempat tinggal selama jangka waktu tertentu. Berdasarkan permasalahan tersebut maka diperlukan sebuah sistem yang bisa memperbaiki sistem lama yaitu dengan membangun sistem perhitungan rancang bangun rumah supaya dapat mempermudah masyarakat yang ingin membeli dan membangun rumah dengan mengetahui perhitungan biaya nya melalui pihak developer. Rancang bangun sistem ini menggunakan bahasa pemrograman PHP dan database MySQL. Implementasi sistem perhitungan rancang bangun rumah ini berbasis web, sehingga masyarakat dapat lebih mudah dalam menggunakan sistem ini dengan mendatangi developer perumahan.
\end{abstract}

Kata Kunci : Perhitungan biaya, Implementasi sistem, PHP, MySQL, Rumah.

\section{PENDAHULUAN}

\section{Latar Belakang}

Pentingnya

Komputerisasi

merupakan salah satu pendukung

berkembangnya teknologi yang telah memasuki hampir ke semua bidang

kehidupan. Perkembangan teknologi ini juga didukung oleh industri hardware (perangkat keras) dan software (perangkat lunak) komputer yang terus berkembang dan semua ini telah memberikan banyak dampak positif bagi kehidupan masyarakat.

Dengan pesatnya teknologi tersebut
kebutuhan masyarakat akan sebuah
pelayanan yang tidak dibatasi ruang dan
waktu saat ini mendorong semakin
dibutuhkannya suatu sistem maupun
perangkat lunak yang akan membantu
proses peningkatan kualitas pelayanan

terhadap customer (pelanggan). 
Salah satu contoh kebutuhan masyarakat yang merupakan kebutuhan pokok manusia yaitu tempat tinggal. Tempat tinggal biasanya berwujud bangunan rumah, tempat berteduh atau struktur lainnya yang digunakan sebagai tempat manusia tinggal. Rumah adalah salah satu bangunan yang dijadikan tempat tinggal selama jangka waktu tertentu. Semakin besar rumah yang akan dibangun maka semakin besar juga biaya yang dikeluarkan untuk pembangunan rumah tersebut. Dan perhitungan biaya dalam pembangunan rumah selama ini dilakukan secara manual. Berdasarkan permasalahan tersebut maka diperlukan sebuah sistem yang bisa memperbaiki sistem lama yaitu dengan membangun sistem perhitungan rancang bangun rumah supaya dapat mempermudah masyarakat yang ingin membeli rumah dengan mengetahui perhitungan biaya nya. Rancang bangun sistem ini menggunakan bahasa pemrograman PHP dan database MySQL

Dalam usaha untuk menuangkan suatu kebutuhan masyarakat tersebut di atas ke dalam penelitian, penulis akan membuat ANALIS SISTEM PERHITUNGAN RANCANG BANGUN RUMAH BERBASIS WEB.

\section{Rumusan masalah}

Adapun permasalahan yang dapat dirumuskan dalam penelitian ini adalah sebagai berikut :
1. Bagaimana merancang dan membangun suatu sistem ataupun perangkat lunak yang menjadi sebuah pelayanan untuk kebutuhan masyarakat dalam cakupan tempat tinggal atau rumah.

2. Bagaimana membuat suatu sistem ataupun perangkat lunak yang melakukan perhitungan biaya pembangunan rumah.

\section{Bagaimana}

mengimplementasikannya dalam bahasa pemrograman PHP dan basis data MYSQL.

\section{Tujuan dan Target Luaran}

Tujuan ini adalah untuk merancang dan membangun suatu sistem ataupun perangkat lunak yang menjadi sebuah pelayanan untuk kebutuhan masyarakat dalam cakupan tempat tinggal atau rumah serta membuat suatu sistem ataupun perangkat lunak yang melakukan perhitungan biaya pembangunan rumah. Dengan adanya sistem ini dapat mempermudah customer (pelanggan) yang ingin membangun rumah dengan mengetahui perhitungan biaya nya. Dan target luaran yang ingin dicapai dalam penelitian ini dapat masuk dan terpublikasi ilmiah dalam Jurnal dan Prosiding

\section{METODE}

Metode penelitian yang dilakukan untuk analisis, merancang dan mengimplementasikan sistem adalah dengan menggunakan metode waterfall, 
melalui tahapan penelitian seperti gambar berikut:

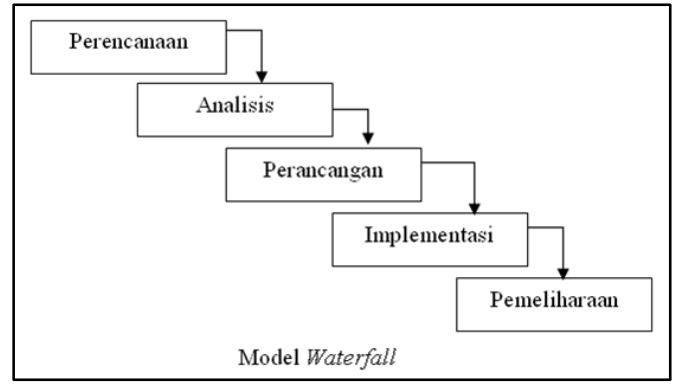

\section{Gambar Metode Waterfall}

\section{Perencanaan}

Teknik pengumpulan data, yaitu proses pencarian data mengenai sistem yang akan dibangun :

1. Studi Literatur

2. Wawancara kepada pihak depelover

3. Observasi langsung ke pihak pekerja (Tukang) untuk mendapatkan informasi dalam pengembangan sistem yang dibuat.

\section{Analisis Sistem}

Penguraian dari suatu sistem informasi yang utuh ke dalam bagian-bagian komponennya dengan maksud untuk mengidentifikasikan dan mengevaluasi permasalahan, kesempatan, hambatan yang terjadi dan kebutuhan yang diharapkan sehingga dapat diusulkan perbaikan. Analisis sistem ini dilakukan pada saat sebelum dibuatnya perancangan sistem, biasa dikenal dengan analisis sistem berjalan, sehingga diketahui permasalan serta apa yang dibutuhkan sehingga dibuat analisis sistem usulan

\section{Desain Sistem}

Suatu proses pemulaian dengan seperangkat tujuan, pengidentifikasian metode umum untuk mencapai tujuan tersebut, dan secara bertahap membuat penyusunan spesifikasi untuk sistem baru yang diusulkan dari rekomendasi yang dibuat selama analisis sitem. Tahap perancangan sistem merupakan gambaran tentang sistem yang akan dibuat serta memahami alur informasi dan proses yang ada dalam sistem. tahap menerjemahkan kebutuhan ke dalam sebuah representasi perangkat lunak, sebelum dimulai pengimplementasian pada kode program. Perancangan sistem ini terdiri dari pengguna yang menggunakan fasilitas internet sebagai media browser, Web server sebagai media penyedia layanan modul PHP, dan Database nya menggunakan MySQL, yang saling terhubung. Sebagai simulasi karena tidak menggunakan jaringan internet, maka menggunakan personal server mempunyai Web server yang berjalan di internet dan admin yang melakukan update data. Gambaran dari Desain pada sistem ini menggunakan Data Flow Diagram (DFD) pada perancangan sistem dan perangkat lunak. DFD merupakan suatu diagram yang menggunakan notasi-notasi untuk 
menggambarkan arus dari data pada suatu sistem, yang penggunaannya sangat membantu untuk memahami sistem secara logika, terstruktur dan jelas.

\section{Implemetasi Dan Uji coba Sistem}

Implementasi sistem adalah mengkonstruksi sistem baru dan membuat sistem tersebut bisa digunakan dalam operasi sehari-hari untuk memenuhi kebutuhan bisnis. [1] Pengimplementasian sistem perhitungan rancang bangun rumah menggunakan WEB Browser yang mana dapat digunakan di perusahaan atau pengusaha yang bergerak dalam bidang properti pembangunan rumah, melalui komputer maupun smart phone.Dalam tampilan sistem ini dirancang semudah mungkin dalam hal penggunaan dan semenarik mungkin. Halaman utama dari sistem ini terdiri atas sebuah kolom tipe rumah yang diinginkan dan bootom submit untuk melihat denah yang sesuai dengan tipe yang dipilih sebelumnya.

Untuk memastikan bahwa sistem ini berjalan sesuai dengan analisis sistem yang diusulkan dan desain sistem maka dilakukan pengujian berupa proses LogIn, link, dan gambar. Pengujian tidak hanya dilakukan dengan mengecek, tetapi juga dengan melakukan input, update dan delete data pada Form yang ada dalam sistem. [2] Pengujian sistem perhitungan rancang bangun rumah berbasis web dengan spesifikasi Processor Intel®CoreTM i3-
2350M, Harddisk 500 GB, Memory 2 GB DDR3. Pengujian dilakukan untuk mengetahui apakah program tersebut berjalan sesuai dengan kebutuhan instansi atau tidak. Pada saat pengujian setiap langkah perlu dicatat sehingga dapat mempermudah perbaikan sistem dan mempermudah dalam pembuatan modul pengoperasian aplikasi perhitungan rancang bangun rumah berbasis web pada dunia industri serta dibuatkan solusi atas kesalahan yang terjadi.

\section{Perawatan Sistem}

Perawatan adalah sebuah kegiatan untuk menjaga dan memelihara sistem agar sistem tersebut terhindar dari kerusakan dan selalu memiliki kinerja yang maksimal dalam pengoperasian. Perawatan hendaknya dilakukan sesering mungkin untuk mengecek peralatan yang digunakan, walaupun tidak ada kerusakan.

\section{HASIL DAN PEMBAHASAN}

Masing-masing kegiatan yang telah dilaksanakan dapat dijelaskan dengan uraian sebagai berikut :

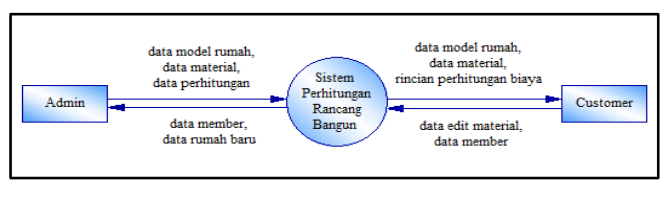

Gambar 1. Diagram Konteks untuk

\section{Implementasi Sistem Perhitungan}

Rancang Bangun Rumah Berbasis WEB 
Flowchart adalah suatu bagan atau chart yang menunjukkan alir atau arus (flow) di dalam program atau prosedur sistem secara logika dalam suatu program [4]. Berikut Flowchart untuk sistem yang dibuat :

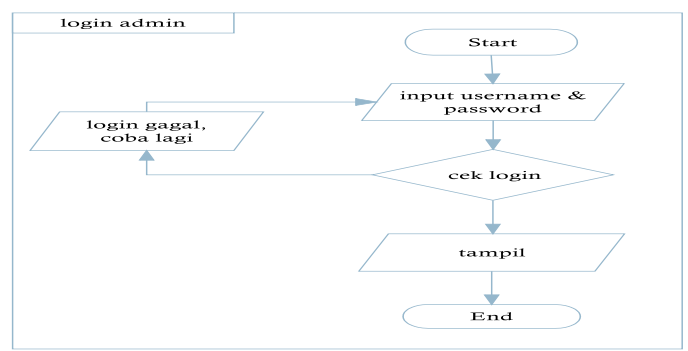

Gambar 2. Flowchart dari login admin

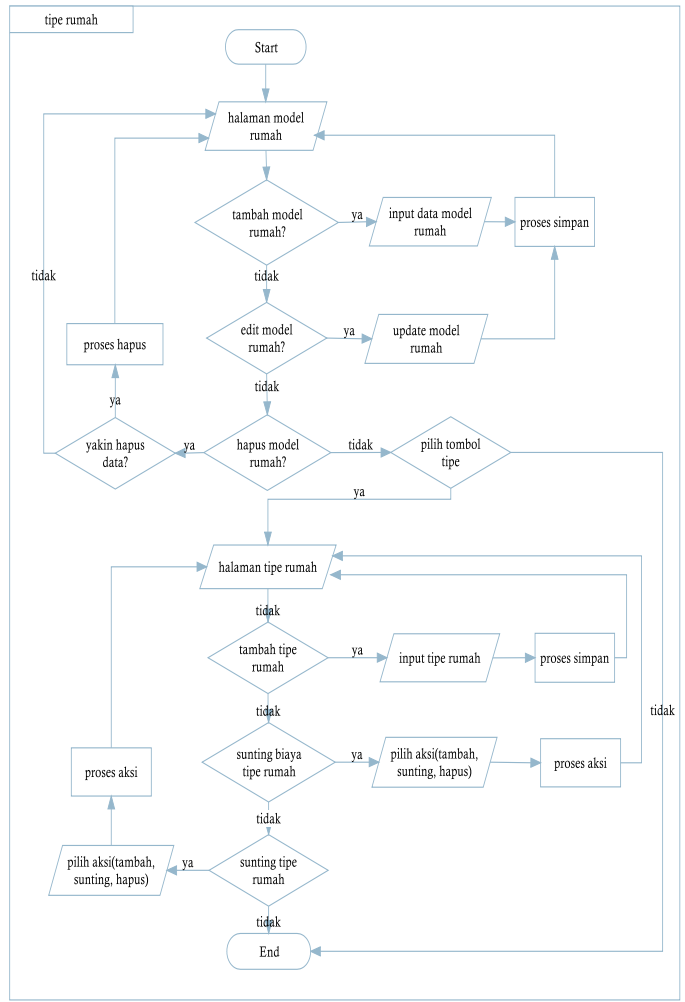

Gambar 3. Flowchart Untuk Form Tipe

Rumah

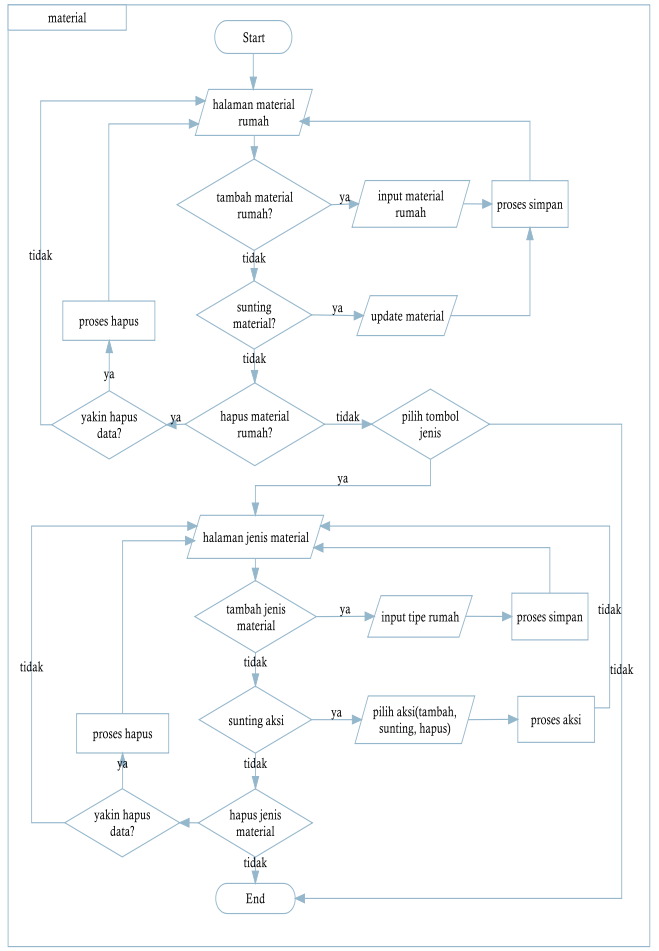

Gambar 4. Flowchart Untuk Form Material

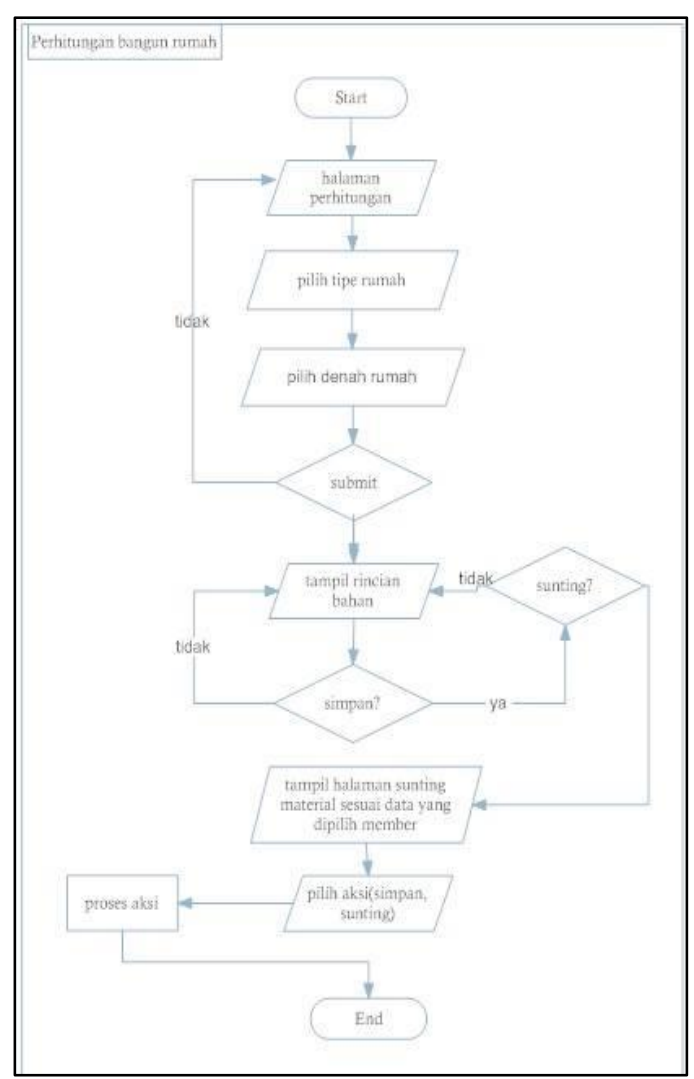

Gambar 5. Flowchart dari form perhitungan bangun rumah. 


\section{Tampilan Sistem Perhitungan Rancang}

\section{Bangun Rumah Berbasis Web}

Home merupakan halaman utama yang berisi sedikit deskripsi tentang rumah dan terdapat sebuah kolom untuk memilih tipe rumah yang diinginkan. Kemudian klik button Submit untuk melihat denah yang sesuai dengan tipe yang di pilih sebelumnya. Tapi sebelumnya harus login terlebih dahulu atau apabila belum terdaftar bisa mendaftar terlebih dahulu dengan mengklik Signup. Seperti pada gambar di bawah ini.

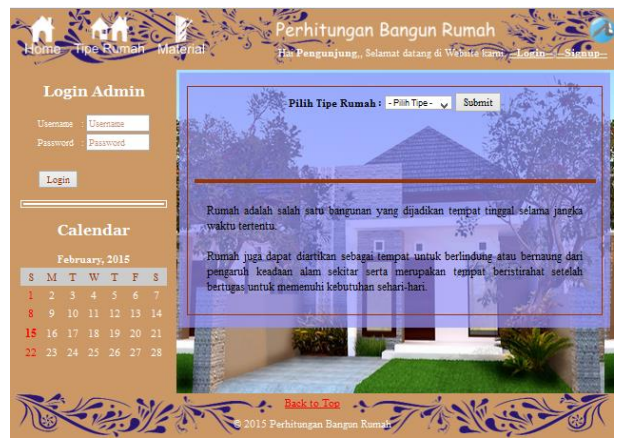

Klik pada denah yang di inginkan untuk mengetahui rincian bahan material dan perkiraan biaya nya.

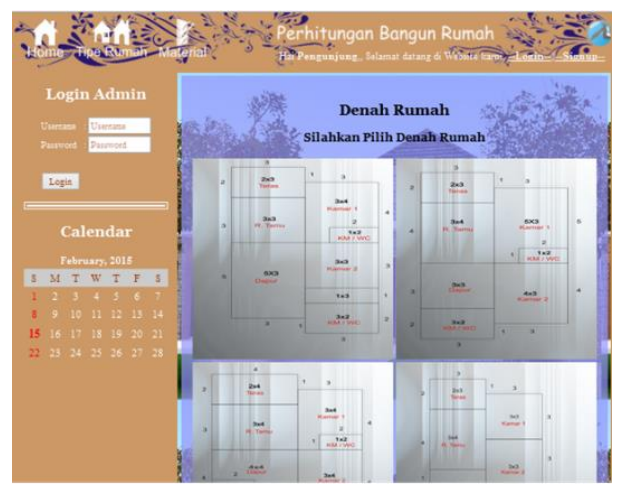

Bahan yang ditampilkan merupakan bahan default awal. Ada bahan yang bisa di ubah seperti Atap, Semen, Keramik, Cat dll.

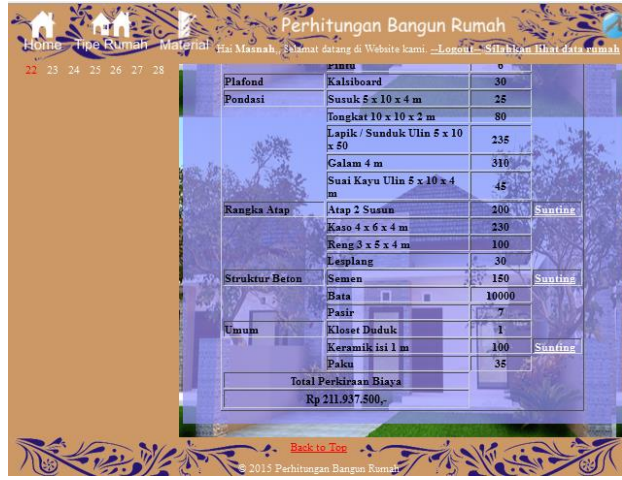

Form Tipe Rumah berisi gambargambar dari masing-masing tipe rumah dan apabila ingin mengetahui data ruangan dan jumlah total perkiraan biaya untuk pembuatan rumah tersebut dengan mengklik gambar rumah tersebut. Untuk mengetahui rincian data bahannya bisa klik pada biaya tersebut, tapi terlebih dahulu pengguna diharuskan login.

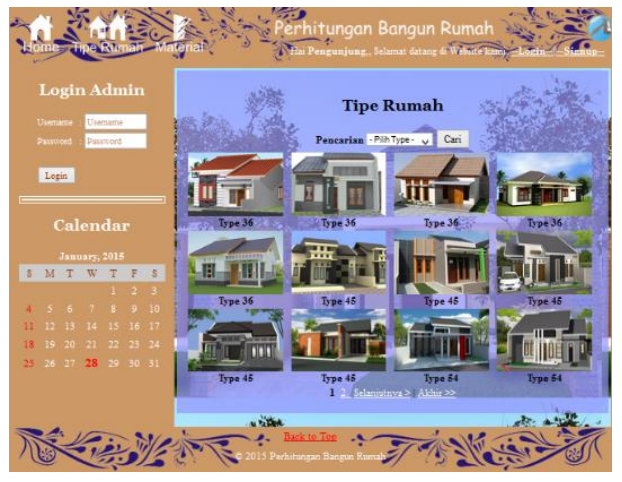

Form Material berisi daftar data-data material bahan yang digunakan dalam pembuatan sebuah rumah, dan pada halaman ini terdapat juga pencarian untuk mencari material berdasarkan jenisnya. 


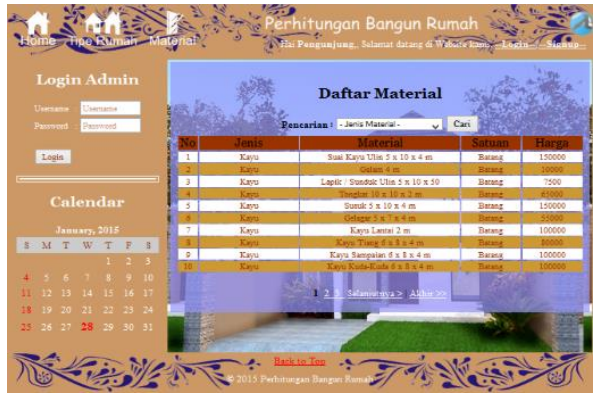

\section{KESIMPULAN}

Kesimpulan yang dapat diambil dari kegiatan penelitian dengan judul "Analisis Sistem Perhitungan Rancang Bangun Rumah Berbasis Web" adalah sistem ini dapat digunakan oleh pihak depelover untuk menyampaikan hasil perhitungan biaya yang dibutuhkan oleh customers (pembeli) dalam membangun rumah berdasarkan denah rumah yang sesuai dengan tipe rumah dan material yang dipilih serta jumlah material yang dibutuhkan dalam membangung rumah impian pembeli.

\section{DAFTAR PUSTAKA}

[1] Haloho. (2007, August 29). Dipetik December 27, 2014

[2] Wibowo, A. M. (2011, April 17). Dipetik December 27, 2014

[3] Nandan, S. (2012, March 08). DIREKTORI FILE Universitas Pendidikan Indonesia. Dipetik August 27, 2014, darifile.upi.edu/:file.upi.edu/Direktori/FPT

K/JUR._PEND.TEKNIK_SIPIL/

Pengertian_Bangunan.pdf

[4] Jogiyanto, H.M., 2005, Analisa dan Desain Sistem Informasi: Pendekatan
Terstruktur Teori dan Praktik Aplikasi Bisnis, ANDI, Yogyakarta 